\title{
“한국의 대아프리카 ODA 정책 방향” *
}

\section{신 장 범 / KOICA 총재}

I. 인사

우선 금번 포럼에 참석한 아프리카 각국 장관 및 학계, 국제기구 귀빈 여러분들을 진심으로 환영 하며, 한국의「대아프리카 ODA 정책 방향」에 대해 서 말씀드리게 된 것을 기쁘게 생각합니다.

지난 3월 노무현 대통령이 아프리카 순방에서 발표한 「아프리카 개발을 위한 한국 이니셔티브」 는 아프리카 개발을 위한 한국의 역할을 강화한다 는 차원에서 중요한 실천적 의미를 지니고 있습니 다. 동 이니셔티브의 일환으로 개최되는 금번 제 1 차 한-아프리카 포럼은 한국과 아프리카의 협력이 점차 확대 발전되는 시기에 개최된다는 점에서 매 우 시의적절하다고 할 수 있습니다.

오늘 본인은 한국의 대외원조 정책기조에 대해
서 소개하고, 이어서 아프리카 지역에 대한 지원 방향 및 계획을 말씀드리도록 하겠습니다.

\section{II. 한국의 대외원조}

과거 선진국의 개발원조 수원국이었던 한국은 현재 세계 12 위의 경제규모를 보유한 국가로 성장 하였으며, 대외원조를 제공하는 국가로 탈바꿈하 였습니다.

한국은 1987년 유상원조(soft loan)인 대외경제 협력기금(EDCF)을 설치하여 개도국의 경제사회 개발을 위한 인프라 구축 사업을 시작하였고, 1991 년 무상원조 전담기관인 한국국제협력단(KOICA) 을 설립하여 개도국 개발역량 강화를 위한 직접적 기술협력 및 무상원조 사업을 수행하여 왔습니다. 
한국은 과거 국제사회로부터 받아온 원조가 오 늘날 한국의 발전을 이루는데 유용하게 쓰였다는 사실을 감안하여 그동안의 국제사회 지원에 대하 여 적절히 보답하여야 한다는 생각을 가지고 있습 니다.

또한 한국의 경제력에 상응한 국제적 책임과 의 무를 부담하고, 1960년초 세계에서 가장 가난한 나라에서 주요 산업국 중의 하나로 성장한 개발경 험을 체계화 - 모델화하여 개도국과 공유해 나가고 자 합니다.

이러한 인식에 기초하여 한국정부는 참여정부 출범 이후 대외개발원조(ODA)를 통한 적극적인 개도국 협력정책을 지속적으로 추진해오고 있습니 다. 한국정부는 개도국의 빈곤완화와 지속가능한 경제사회 발전을 위한 지원을 목표로 UN 천년목 표(MDG) 등 국제사회의 개발협력 목표 달성 및 범지구적 과제해결 공동노력에 적극 동참하고 있 습니다. 특히 중기 재정운용계획 수립을 통해 우리 의 국제사회 기여에 대한 확고한 의지를 표명하고, 구체적인 목표를 정한 바 있습니다. 동 중기 재정 운용계획에 따라 2009년까지 GNI의 0.1\%, 2015 년까지 GNI의 $0.25 \%$ 의 ODA 예산을 확보하기로 하였습니다.

이와 같은 목표를 기초로 한국국제협력단은,

첫째, 개도국 수요에 부합하고 우리 개발경험
공유가 가능한 사업 즉 인적자원개발(HRD) 및 정 부역량강화(Capacity Building) 분야에 중점 지원 하고 있습니다.

둘째, 빈곤완화, 기초보건, 초등교육 등 인간기 본욕구(BHN) 분야와 여성인권, 환경 등 범지구적 과제에 대한 지원을 강화하고 있습니다.

그리고 최근 개도국에서 빈번히 발생하고 있는 지진, 태풍 등의 자연재해에 대해 신속한 재난구호 와 복구체제를 마련하였습니다.

\section{III. 아프리카 지역에 대한 지원 방향 및 계획}

2006년 3월 노무현 대통령은 아프리카 순방시 「아프리카 개발을 위한 한국 이니셔티브」의 발표 를 통해 2008년까지 한국의 대 아프리카 ODA를 3 배로 확대하겠다고 천명하였습니다.

아프리카 개발 이니셔티브에 나타난 바와 같이 한국정부는 한국의 개발경험 공유를 통한 아프리 카 각국의 능력배양(Capacity Building)을 지원할 예정입니다. 향후 3 년간 총 2 천명 이상의 아프리 카인을 초청하여 연수시키고, 아프리카에 봉사단 파견을 확대해 나갈 계획입니다.

한국국제협력단은 동 이니셔티브의 이행을 위 
하여 아프리카에 대한 무상원조 예산을 2006년도 전체예산의 $9 \%$ 에서 2009 년도에는 $20 \%$ 까지 확대 한다는 계획을 수립하였습니다.

한국국제협력단은 대 아프리카에 대한 원조가 보다 수원국 현실에 부합되고 실질적인 효과가 나 타날 수 있도록 노력을 경주하고 있습니다. 아프리 카에 대한 중점 지원분야를 교육, 보건, 농촌 개 발, 행정제도, ICT 등 5 개로 정하고, 협력대상국별 로 원조정책을 수립하여 체계적인 원조를 추진하 고 있습니다.

분야별로 주요내용을 설명 드리자면,

우선 한국의 개발과정에서 가장 중요한 요인이 라고 평가되는 인적자원개발 분야의 지원을 위해 빈곤소외계층에 대한 교육기회 확대, 직업훈련을 통한 노동 인력의 취업기회 확대를 지원할 계획입 니다. 이를 위해 초등학교시설 신축. 개선 확충, 교육정책 및 제도개선, 교과과정 및 교재개발, 직 업훈련원 건립 등을 실시할 예정입니다.

둘째, 기초의료 서비스 개선, 영유아 및 아동사 망률 감소, 모성보건 증진, HIV/AIDS 및 말라리 아 등 주요 질병퇴치를 지원할 계획입니다. 이를 위해 의료시설 지원, 보건의료 정책 및 제도 개선, 의료인력 양성, 의료 기자재 및 의약품 지원 등을 실시할 예정입니다.

또한, 동아프리카 한발피해 대상국인 에티오피
아, 탄자니아, 케냐, 르완다, 우간다, 지부티 등에 대하여 식수공급시설 개선 및 확충, 관정개발 및 보수, 식수난 해소를 위한 정책적/기술적 역량강 화를 지원할 계획입니다. 이를 위하여 국제협력단 은 06.5 월 에티오피아, 케냐, 지부티 3개국에 사 업형성조사단을 파견한 바 있고, 11 월 현재 에티오 피아, 케냐 2 개국에서는 관정개발 지원사업을 추 진 중에 있습니다. 또한 탄자니아에서는 12 월에 사 업을 착수할 예정입니다.

셋째, 아프리카 식량 문제 해결 및 1 차 산업 육 성을 위해 농업 및 수산업 분야 프로그램 지원을 강화해 나갈 계획입니다. 한국의 농수산 분야 발전 경험과 기술을 바탕으로 농어업기술, 농촌개발 등 지원을 통하여 아프리카의 국가들의 농업생산성 향상 및 농가소득 증대에 기여해 나갈 예정입니다.

넷째, 우리의 정부 주도형 개발경험 전수, 정부 행정능력 강화, 행정제도 개선 등을 지원할 계획입 니다. 이를 위해 알제리, 이집트 등 아프리카 국가 만을 대상으로 한 맞춤식 국별 연수과정을 개설하 고, 경제개발, 산업육성, 재정정책 등 테마별 프로 그램을 지원할 예정입니다.

마지막으로, 정보통신 인프라 구축(통신망, 전 산망 등), 정보통신 정책 및 제도 구축, 전자정부 (e-government) 구축, 정보통신 인력 교육훈련, 정보통신 기본 장비 제공 등을 지원할 계획입니다. 
현재 한국정부는 국제사회의 빈곤과 질병퇴치 를 위한 인도주의적 사업에 사용하기 위하여 항공 권 연대기여금 제도의 도입을 추진중입니다. 동 항 공권 연대기여금 제도는 국회 입법절차가 완료 되 는대로 내년 상반기중 시행될 것으로 예상되고 있 습니다. 한국 정부는 동 재원을 아프리카 빈곤퇴치 에 집중 사용하는 방안을 검토 중입니다.

그리고 아프리카 지역에 대한 양자차원의 지원 과 함께 다자차원의 협력사업도 확대해 나갈 계획 입니다. 아프리카 개발지원과 관련하여 전문성 및 네트워크를 갖춘 국제기구와의 공동협력사업을 추 진할 예정입니다. 특히 내년부터 아프리카 국가들 의 무역정책 능력 강화를 위한 인적자원 육성을 위 해 UNDP와 공동협력사업을 추진할 계획이며, 그 밖에 UNFPA, NEPAD 등의 의료 및 농업분야 사 업에도 적극 참여할 예정입니다.

\section{IV. 맺음말}

아프리카 국가들의 발전에 대한 열망을 누구보 다도 잘 이해하고 있는 한국은 그 발전 경험을 계 속 공유해 나갈 것입니다.
한국은 전쟁 및 가난을 극복하고 반세기 만에 원조를 받던 나라에서 원조를 주는 나라로 발전한 유일한 국가로, 이러한 한국의 개발경험은 아프리 카의 많은 국가들에게 유용하게 활용될 수 있을 것 이라 믿습니다.

아프리카의 풍부한 성장 잠재력과 한국의 개발 경험이 함께 한다면 발전을 위한 상승효과를 기대 할 수 있으며, 아프리카와 한국의 상호 협력이 더 욱 발전될 수 있을 것이라고 생각합니다.

한국은 앞으로도 아프리카 국가들과 우리의 발 전경험을 적극 공유할 계획이며, 아프리카 국가들 이 성장 잠재력을 키워 나갈 수 있도록 지원하고자 합니다.

감사합니다. 